\title{
ANALISIS PEMASARAN CALON GUBERNUR AHOK DI PILKADA DKI 2017
}

\author{
Rahmat Gunawan \\ Program Studi Managemen Fakultas Ekonomi Universitas Djuanda Bogor \\ Email : rahmat.gunawan@unida.ac.id
}

\begin{abstract}
This paper describes how to apply marketing science in politics, especially marketing science services with dimension of TERRA to market a candidate of Regional Head in DKI Jakarta. Establishment of marketing team or campaign team as well as emphasis of marketing program of a Jakarta Cagub should be done and how to respond to community response as voter candidate in Pilkada. In addition, the discussion also touches on the atmosphere of competition and the theme of what programs should be conveyed to the prospective voters market. Another thing that is discussed related to the survey about the market desire about what service products are expected from a Cagub who, if in accordance with their expectations would be an option in Voting Election DKI Jakarta 2017.
\end{abstract}

Keywords: Marketing, TERRA Dimension, and Service Marketing Mix

\begin{abstract}
ABSTRAK
Makalah ini menjelaskan tentang bagaimana caranya menerapkan ilmu pemasaran dalam bidang politik khususnya ilmu pemasaran jasa yang berdimensi TERRA untuk memasarkan seorang kandidat Kepala Daerah di DKI Jakarta. Pembentukan tim pemasaran atau tim kampanyenya serta penekanan program pemasaran seorang Cagub DKI yang seharusnya dilakukan dan bagaimana menanggapi respon masyarakat sebagai calon pemilih di Pilkada. Selain itu pembahasannya juga menyinggung tentang suasana persaingan dan tema program apa yang harus disampaikan pada pasar calon pemilih ini. Hal lain yang dibicarakan yaitu berkaitan dengan survey tentang keinginan pasar tentang produk jasa apa yang diharapkan dari seorang Cagub yang jika sesuai dengan harapan mereka tentu akan menjadi pilihan di Pemungutan Suara Pilkada DKI 2017.
\end{abstract}

Kata Kunci: Pemasaran, Dimensi TERRA, Bauran Pemasaran Jasa

\section{PENDAHULUAN}

Pilkada DKI Jakarta tahun 2017 kemarin yang hingar bingar dan sengit persaingan dengan hasil yang diluardugaan dimana sang Incumbent yaitu Basuki Tjahaya Purnama dan pasangannya Djarot atau popular dengan sebutan Ahok- Djarot tersungkur di tangan sang Penantangnya yaitu Anies-Sandi yang sejak awal bahkan tidak diunggulkan.
Ahok-Djarot dengan dukungan berbagai macam parpol seperti PDIP, Hanura, Nasdem, Golkar, PKB dan mendapat dukungan habishabisan dari para konglomerat penyandang dana besar secara mengenaskan takluk di tangan Anies-Sandi yang didukung hanya Gerindra, dan PKS. Suatu kejutan yang luar biasa.Secara rasional PDIP dan Golkar adalah parpol besar yang selama ini menguasai panggung politik nasional. Mereka sudah berpengalaman 
bertahun-tahun di bidang politik akhirnya tumbang secara mengenaskan di tangan hanya dua parpol yang relatif secara kader kecil dan belum seberpengalaman seperti mereka. Apa rahasia besar di balik kejadian ini? Studi ini mencoba untuk menganalisis beberapa faktor yang dapat menyebabkan terjadinya hal ini.

\section{MATERI DAN METODE}

Hasil Pilkada DKI putaran pertama menunjukkan Ahok Djarot mendapatkan dukungan sebesar 2.364.577 suara atau 42,99\%, Agus Sylvi sebesar 937.955 suara atau 17,07\%, dan Anies Sandi sebesar 2.197.333 atau 39,5\% (KPU DKI 2017). Hasil ini menunjukkan betapa kuatnya tingkat dukungan berupa elektabilitas dan popularitas Ahok-Djarot dibandingkan dengan kedua pasangan yang lainnya maka walaupun ada pemungutan suara di putaran kedua diprediksi Ahok-Djarot akan memenangkan Pilkada DKI dengan mengalahkan pasangan lawannya yaitu AniesSandi. Dan dengan kondisi hasil putaran pertama ini akhirnya menjadi dasar pelaksanaan putaran dua mengingat Pilkada DKI putaran pertama tidak menghasilkan pasangan calon yang mendapatkan dukungan dominan secara mutlak maka akhirnya dilaksanakan putaran kedua yang menghasilkan komposisi dukungan sebagai berikut: Ahok-Djarot mendapatkan dukungan sebesar 42,05\% dan pasangan AniesSandi $57,95 \%$. Hasil ini sangat diluar dugaan banyak pihak termasuk oleh para pendukung pasangan incumbent Ahok-Djarot ini. Dan hal ini menjadi fenomenal karena Pilkada DKI adalah Pilkada rasa Pilpres karena sifatnya yang menasional.

\section{HASIL DAN PEMBAHASAN}

Maka berdasarkan data hasil diatas dapat dianalisis kenapa hal seperti ini bisa terjadi:

1. Situasi yang terjadi adalah pasangan Ahok-Djarot tidak melaksanakan teori pemasaran secara benar terutama pelaksanaan pemasaran calon kepala daerah yang lebih ditekankan pada produk-produk jasa maka sifat penilaian dapat dikembalikan secara teori berdasarkan dimensi utama penilaian kualitas jasa yaitu pada pelaksanaan dimensi TERRA atau Tangible (berwujud), Emphaty (perhatian), Responsiveness (cepat tanggap menanggapi permasalahan) serta Reliability (mewujudkan janji) dan Assurance (jaminan) seperti dijelaskan oleh Lupiyoadi dalam Manajemen Pemasaran Jasa (2001). Selain itu pemasaran seorang Kepala Daerah dilaksanakan dengan menerapan bauran pemasaran jasa atau service marketing mix seperti dijelaskan oleh Lupiyoadi (2001) dan Hasan (2008) serta Hartanto (2017).

2. Bagaimanapun Ahok Djarot ini adalah incumbent, artinya pasangan petahana yang seharusnya mampu membuktikan keberhasilan mereka pada calon pemilih yang berkaitan dengan program pembangunan fisik selama memimpin ibukota. Hanya sayang di pelaksanaan perwujudan pembanguna fisik ini komunikasinya mereka tidak lancar misalnya tentang masalah keberwujudan program pembangunan mereka yang justru kelihatan terlalu bersifat mengabaikan kepentingan rakyat banyak yang merupakan golongan ekonomi bawah dan menengah tapi lebih memperhatikan kepentingan masyarakat golongan ekonomi atas misalnya para pengusaha dan para konglomerat. Contoh kecil adalah tentang reklamasi pantai utara Jakarta yang menyingkirkan kepentingan para nelayan Jakarta yang berkemampuan ekonomi lemah di saat yang sama mengutamakan kepentingan para pengusaha dan konglomerat serta etnis tertentu.

3. Secara empathy atau perhatian AhokDjarot ini kurang perhatian terhadap masyarakt ekonomi lemah terutama para 
pedagang kecll.Contohnya adalah penggusuran PKL di Tanah Abang dan berbagai penggusuran masyarakat kecil lainnya di berbagai sudut ibukota. Selain itu misalnya bagaimana Ahok memperlakukan secara kasar para PNS DKI serta seorang ibu yang sedang menanyakan Kartu Jakarta Pintar dengan sebutan maling dan lain-lain.

4. Secara responsiveness atau cepat tanggap Ahok-Djarot ini kurang tanggap terhadap permasalahan yang menimpa masyarakat misalnnya tentang kemacetan, banjir, dan lain-lain dimana yang selalu disalahkan adalah pihak lain atau masyarakat sendiri bukan pemerintah selaku pengatur kebijakan pembangunan.

5. Secara reliability bagaimana seorang Mayjen Priyanto mengutarakan kekecewaannya pada seorang Ahok yang tidak berkomitmen membuktikan dan menuntaskan janjinya untuk memberantas kasus korupsi Jokowi di Taman BMW padahal dokumennya sudah beliau serahkan pada Ahok sebagai Gubernur dan KPK.

6. Secara Assurance atau jaminan Ahok tidak mampu memberikan janji yang mampu menuntaskan harapan masyarakatnya misalnya penuntasan masalah banjir, penampungan korban penggusuran di rumah susun yang seharusnya gratis ternyata malah berbayar dan lain-lain

Hal-hal di atas yang berkaitan dengan factor dimensi TERRA atau Kualitas Jasa ini menjadi faktor penghalang pasangan incumbent untuk mampu tampil kembali memimpin DKI Jakarta 5 tahun ke depan. Awalnya tidak terasa dan tidak terlihat sebagai faktor yang akan menjatuhkan tapi ternyata terbukti menjadi serangan mematikan dari para pesaingnya untuk menjatuhkan citra baik sang incumbent di mata pemilihnya.
1. Selain pelaksanaan dimensi TERRA yang tidak sesuai harapan faktor penyebab kegagalan yang lainnya adalah tidak berjalannya komunikasi pemasaran yang baik yang ditandai dengan proses komunikasi yang macet antara pasangan calon dengan calon pemilih. Secara program pembangunan terutama infrastruktur Ahok-Djarot mampu membangun dengan baik.tapi bahasa komunikasi pemasarannya terutama dari sang Ahok sendiri sebagai alon Gubernur gagal meyakinkan pemilih untuk memilihnya saat pemungutan suara akibat karakter komunikasi Ahok yang arogan dan cenderung ingin dipahami oleh pasar pemilihnya padahal seharusnya pemasar itu memahami pasar bukan pasar memahami pemasar. Hal ini bisa terlihat dengan penggunaan komunikasi yang cenderung satu arah dimana apapun yang dikatakan Ahok adalah benar dan yang dikatakan yang bukan Ahok adalah tidak benar. Berbagai macam isu yang menimpa Ahok dijawab dengan karakter seperti ini dari mulai isu SARA hingga isu TPS Bantargebang isu Sumber Waras dll sehingga membuat para calon pemilih bisa menyimpulkan bahwa Ahok diktator dan tidak mau mendengar pendapat orang lain serta bersikap sok kuasa bahkan berani memaki-maki orang atau lembaga yang tidak bersesuaian pendapat sebagai pihak yang selalu salah dari mulai Pemda dan DPRD Bekasi tentang masalah TPS Bantargebang hingga BPK yang menyelidiki kasus Ahok di Sumber Waras. Semua adalah salah dan Ahok selalu benar.

2. Hal lain dan termasuk yang menentukan adalah sikap Ahok berkaitan dengan umat islam yang mayoritas di Indonesia dan Jakarta khususnya. Ahok bukannya mendekati umat Islam yang ada adalah memusuhinya padahal sudah jelas mayoritas pemilih adalah beragama 
islam maka hal apapun yang berkaitan dengan pelecehan agama mereka oleh Ahok menjadi sumber keputusan tidak memilih Ahok dalam kegiatan Pilkada DKI 2017 ini. Dan hal ini menjadi bukti dengan terjadinya berbagai kegaduhan saat Kampanye Pilkada DKI terutama yang bernuansa agama dengan terjadinya banyak demonstrasi dari para ulama dan ustadz serta santri dan umat Islam yang mewakili Majelis Ulama Indonesia(MUI) terhadap kasus pelecehan ayat Quran Al Maidah ayat 51 di Kepulauan Seribu yang menimbulkan dampak luar biasa hingga segala perhitungan rasional luluh lantak saat pemungutan suara di bilik suara akibat tindakan Ahok yang tidak jelas arah ini.

3. Tim Kampanye Ahok tidak jeli memanfaatkan potensi untuk mendekatkan diri pada masyarakat terutama umat islam Jakarta dengan berbagai program persuasif yang bisa mengurangi kesenjangan antara citra Ahok yang tidak ramah pada Islam dengan kampanye kehumasan yang sifatnya menjelaskan visi misi Ahok sebagai Gubernur dan Calon Gubernur. Dengan berbagai program pemasaran politik dari mulai membangun masjid hingga pengentasan kemiskinan dan haji serta umroh. Hal seperti itu bahan tidak ditekan secara kuat

4. Dilihat berdasarkan bauran pemasaran produk khususnya bauran pemasaran jasa yang berkaitan dengan 3P atau People, Process hingga Physical Evidence atau bukti fisik ini langkah Ahok terlihat kian limbung. Bagaimanapun juga proses pemasaran jasa lebih rentan karena ciri produk jasa yang berbeda dengan produk barang misalnya saat penyampaian dimana produk jasa waktu produksi sama dengan waktu konsumsinya. Maka blunder Ahok yang menyinggung perasaan umat Islam terutama berkaitan dengan surat $\mathrm{Al}$ Maidah ayat 51 ini menjadikan proses pemasarannya sebagai calon Gubernur saat kampanye semakin sulitkarena antipati Ahok pada umat Islam langsung terasakan saat itu juga.untuk meraih simpati publik seharusnya Ahok melakukan pendekatan pada umat Islam yang terjadi adalah proses permusuhan bahkan saling caci maki. Maka akibatnya semakin dapat diprediksi. Ahok pun menjadi musuh publik. Segala sesuatu yang berbau Ahok dihindari. Sangat jauh dari proses pemasaran yang seharusnya terjadi saat kampanye. Dimana sang calon kepala daerah yang seharusnya dielu-elukan yang terjadi malah menjadi ladang caci maki. Selain itu secara people atau melihat program pemasaran dikaitkan dengan kapasitas SDMnya hubungan komunikasi yang seharusnya hangat menjadi tertutup. Yang ada adalah hubungan komunikasi tertutup antara hanya Ahok dengan pendukungnyasaja tidak dengan semua calon pemilihnya saat putaran pertama dan kedua digelar. Hubungan komunikasi pemasaran yang seharusnya disampaikan untuk memikat pemilih sama sekali tidak berjalan pada jalur yang seharusnya. Komunikasi pemasaran macet total dan berjalan lancar hanya khusus dengan para pendukungnya saja.

5. Hal yang menarik yang mengemuka saat Pilkada DKI digelar adalah mencuatnya isu agama menjadi isu yang menentukan pilihan para pemilihnya. Quran Surat Al Maidah ayat 51 menjadi sumber perdebatan dan sumber tema kampanye hingga menimhulkan suasana gaduh tingkat nasional. Bagaimanapun juga posisi Ahok yang memang berada pada posisi yang tidak menguntungkan karena berasal dari etnis Tionghoa yang selama ini termarjinalkan kemudian juga beragama Kristen padahal pasar pemilihnya mayoritas Islam itu juga menjadi kendala penentu yang seharusnya diterobos dengan pendekatan 
untuk meraih simpati dengan bahasa hubungan masyarakat yang persuasif untuk membuat Ahok dapat diterima oleh pasar pemlih tetapi pendekatan yang ada adalah pendekatan diplomasi megaphone alias teriak-teriak sehingga hasil yang timbul adalah suasana menantang dan frontal sehingga kedatangan Ahok pada beberapa wilayah untuk berkampanye pun bahkan ditolak secara massif oleh calon pemilih.

Berdasaran pembahasanan di atas maka akhirnya akan dapat dimengerti kenapa seorang incumbent seperti Ahok yang seharusnya dengan posisi yang telah didapatkan sebagai incumbent dapat menjadi modal untuk bersaing tidak bisa dimanfaatkan dengan sebak-baiknya yang berujung pada kekalahan yang sangat mengejutkan khalayak ramai secara nasional maupun internasional.

\section{KESIMPULAN DAN IMPLIKASI}

Hasil Pilkada DKI menunjukkan betapa pendekatan pada masyarakat secara langsung dengan berbagai metode kualitas jasa dan bauran pemasaran jasa apakah dengan penerapan dimensi TERRA maupun personal selling, humas, hingga komunikasi dari mulut ke mulut atau penekanan pada proses orang dan bukti fisik masih sangat diperlukan untuk bisa memasarkan calon kepala daerah pada para calon pemilihnya. Pemahaman akan target pasar serta apa kebutuhan mereka terlihat sangat diabaikan terutama oleh para pengambil kebijakan pada berbagai parpol pendukung incumbent sehingga program pemasaran tidak tepat sasaran dengan pendekatan yang justru tidak diterima pasar pemilih. Maka kegagalan sang Incumbent menunjukkan betapa komunikasi politik pemasaran calon kepala daerah lebih didominasi keputusan para pimpinan parpol tanpa mempedulikan suara dan harapan para pemilih sebagai pasarnya sehingga terjadi hal yang diluar dugaan yaitu tragisnya nasih sang Ahok sebagai incumbent dalam pagelaran Pilkada DKI tahun 2017 ini.

\section{DAFTAR PUSTAKA}

Hasan, Ali, 2008, Marketing, PT Buku Kita, Jakarta

Hartanto, Eko, 2017, Bauran Pemasaran Jasa www. academia.edu

Lupiyoadi, Rambat, 2001, Manajemen Pemasaran Jasa, Salemba Empat, Jakarta

Pilkada DKI, 2017, KPU DKI, Jakarta

Syahirul Alim, 2016, Strategi Politik Ahok di Pilkada DKI, Kompasiana 